\title{
Impact of economic growth on international reserve holdings in Brazil
}

\author{
Impacto do crescimento econômico sobre \\ as reservas internacionais do Brasil
}

MOHAMMAD KASHIF

P. SRIDHARAN

S. THIYAGARAJAN *

\begin{abstract}
RESUMO: Este estudo investigou o impacto do crescimento econômico sobre as reservas internacionais brasileiras no contexto do Mecanismo de Correção de Erros, utilizando dados do período 1980-2014. Os resultados revelam que o crescimento econômico é altamente significativo. A partir da estimativa do nosso modelo, argumentamos que o crescimento econômico e as reservas internacionais têm relação positiva de longo prazo. Error correction estimates validated our model for error correction term is negative and statistically significant. Além disso, nosso modo sugere que o crescimento econômico também tem relação de curto prazo. A velocidade de ajuste é mais de $40 \%$, indicando que o termo de correção de erro corrige o desequilíbrio do ano anterior à taxa de 40,4\%.

PALAVRAS-CHAVE: Brasil; crescimento econômico; modelo de correção de erros; reservas internacionais.
\end{abstract}

ABSTRACT: This study investigated the impact of economic growth on Brazilian international reserves holdings in the context of Error Correction Mechanism using data over the 1980-2014 period. The results reveal that economic growth is highly significant. From the estimation of our model, we argue that economic growth and international reserves have positive long run relationship. Error correction estimates validated our model for error correction term is negative and statistically significant. Besides, our model suggested that economic growth has short run relationship too. The speed of adjustment is more than $40 \%$ which indicated that error correction term corrects previous year disequilibrium at the rate of $40.4 \%$.

KEYWORDS: Brazil; Economic Growth; Error correction model; International reserves. JEL Classification: F41; F43; F62.

\footnotetext{
* Research Scholar, Department of International Business, School of Management, Pondicherry Central University, India. E-mail: mkashif69@gmail.com., Associate Professor \& Head, Department of International Business, School of Management, Pondicherry Central University, India. E-mail: psridharan@lakshmisiri.com, Assistant Professor, Department of International Business, School of Management, Pondicherry Central University, India. E-mail: thiyagarajan.ibm@pondiuni.edu.in
} 


\section{INTRODUCTION}

International reserves or foreign exchange reserves are a country's external assets that include gold, Special Drawing Rights (SDRs), foreign currency deposits and bonds held by central banks and monetary authorities. According to International Monetary Fund, international reserves are "Those external assets that are readily available to and controlled by the monetary authorities for meeting balance of payments financing needs, for intervention in exchange rate markets to affect the currency exchange rate, and for other related purposes" (IMF's BPM6, 2014). The top ten holders of international reserves account for nearly two-thirds of the world's total international reserves. China, with USD 3.86 trillion at the end of 2015, tops the list. Ten years ago it had only USD 822 billion. Second is Japan with USD 1.2 trillion (as on Jan' 2016). The list is going on but Brazil comes on eighth position with USD 358,799 million as of Jan' 2016. There is an increasing debate about the need to have large stocks of foreign exchange reserves.

Research on international reserves was started during 1960s particularly when Heller (1966) presented the estimations of the optimum level of international reserves by comparing marginal cost to marginal benefit. Balassa, B. (1977) employed Brazil as one of the countries in his sample and found that exports growth favorably influences the rate of economic growth over the contributions of domestic and foreign capital. Mendoza, R. (2004) considers that reserve management in emerging countries is motivated by precautionary purposes against financial crises. Chin-Hong et al. (2011) found a positive relationship between economic growth and international reserves in case of Malaysia. The same results are derived by Irefin and Yabaa (2012) for Nigerian economy. Gonzaga, F. (2003) applied Thirlwall's BoP model to economic growth in Brazil and found that the external constraints affect strongly the pattern of economic growth. Malloy, M. (2013); Ostry et al. (2011) investigate that a number of factors may affect the foreign exchange reserves, they presented three main determinants-first, to smooth short run fluctuations of exchange rate; second, reserves are accumulated for precautionary and third for competitive motives. Feder, G. (1982) suggested that economic growth based on foreign trade and external sector policies is reasonable as these policies take the economy close to optimal allocation of resources. Bacha, E. (1977) stated that foreign capital had a persistent and dynamic role in economic growth in Brazil.

The amount of global international reserves is one of the highest in history. Additionally, the reserve holdings pattern has been increasing at a faster pace since early 1990s. Figure 1 shows the reserve volumes over the 1980-2014 sample period for Brazil. It clearly illustrates that Brazil accumulating international reserves at a fast pace. It also shows that the amount of international reserves continuously increasing since 1990. 


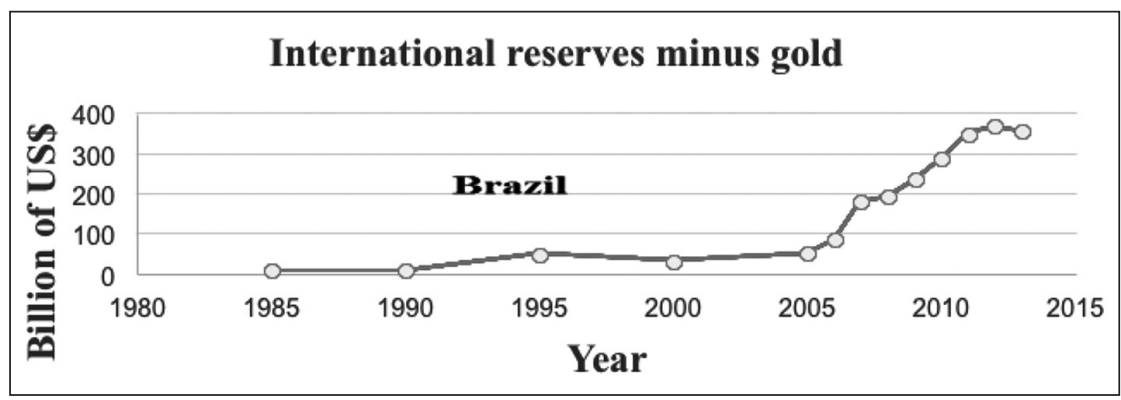

Source: Authors' calculations based on WDI data.

Countries in the world usually hold international reserves to have a favorable level of exchange rate especially with a view to stabilizing it and maintenance of other economic activities. There has been a continuous debate whether there is a need to beef the level up of countries' international reserves or trim them back, and this debate is becoming more interesting especially in developing countries. Current researches argued that the international reserve position determines the country's rating in the global competitive market. In other words, these proponents hold the view that a robust level of reserves will make the country appear financially responsible and creditworthy in the eyes of other countries, creditors and donors (Ford and Huang, 1994).

In this study, we provide empirical findings on the issue of influencing international reserves by a macroeconomic variable such as economic growth in case of Brazilian economy by employing error correction mechanism. We demonstrate that economic growth and international reserves have positive long run relationship. The rest of the paper is organized as: after this introduction, second section presents some relevant literature review, third section provides objectives of the study, fourth section deals with data and methodology employed, fifth section discusses empirical results following the limitations of the study under sixth section. Last section concludes.

\section{LITERATURE REVIEW}

Research on international reserves was started during 1960s, 1970s, and 1980s. During these time, research was focused primarily on ascertaining the effects of the Bretton Woods system, and its failure, laid on international reserves. The large accumulation of foreign reserves, contrary to what was forecasted, has compelled researchers to revisit the issue again and explain why the facts seem to contradict the theory. Most of the current researches stand from the theories developed in early 1970s and 1980s.several models have been developed to measure the factors impacting international reserves. 
According to IMF (2009), Foreign exchange reserves are foreign currency deposits of central banks or other monetary authorities. They are assets of central banks held in different reserves currencies such as the dollar, pound sterling, euro, yen etc. These reserves currencies are used to back central bank's liabilities, such as the local currency issued, the reserves deposits of various deposit money banks, government or other financial institutions. International reserves are used to support monetary and foreign exchange policies, in order to meet the objectives of safeguarding currency stability and the normal functions of domestic and external payment systems. From the onset, foreign reserves were held in gold, but with the advent of the Bretton Wood system, the US dollar was pegged to gold and the gold standard was abandoned. Hence, the dollar, appearing as good as gold, became the fiat and most significant reserves currency.

Figure 2: International Reserves as \% of Total External Debt

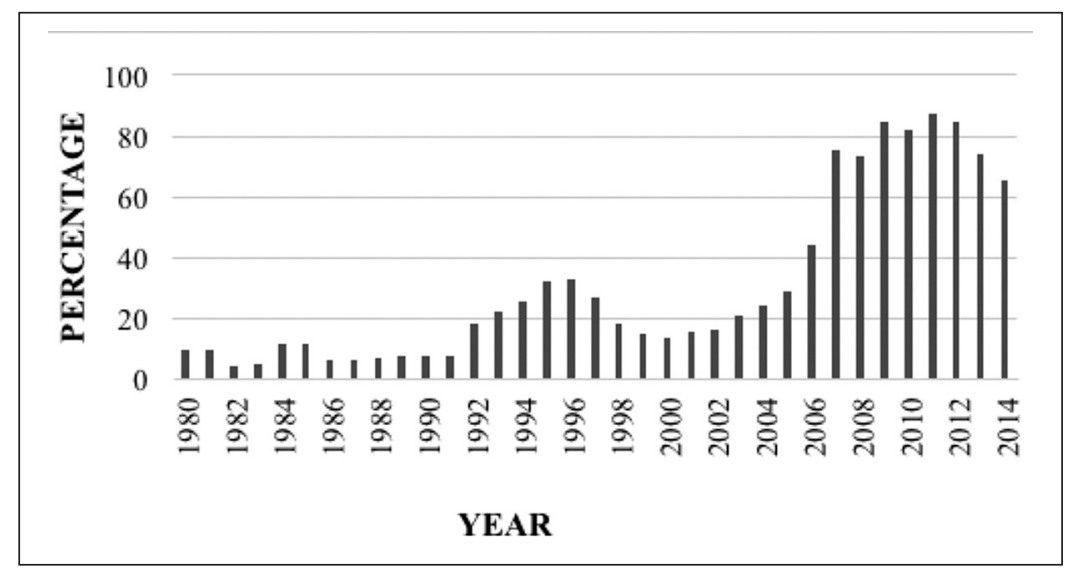

Source: Authors' calculations based on WDI data

Frenkel (1981), stated that the marginal propensity to import (MPI) determines openness to external shocks of an economy and should be positively related to international reserves if the reserves were held as a precautionary motive. Frenkel measured a country's MPI as the ratio of imports over GDP. His study concluded that "optimal reserve holdings would increase as the volatility of reserves increased." His empirical study explained that volatility of reserves is really a robust factor that lays high impact on international reserves.

Aizenman and Marion (2003) focused on the demand for international reserves in the Far East compared to the demand in other developing countries. Their study found that reserve holdings for the 1980-1996 periods were the outcome of several factors such as: international transactions, international transaction's volatility, the exchange rate arrangement, and political considerations.

Robitaille P. (2011) examined the Brazilian experience prior to and during the global crisis as a case study that can shed light into the challenges of using reserve requirements as a liquidity management tool. He mentioned that Brazilian reserve 
requirements did not ensure adequate liquidity, in part because the smallest banks were exempted from the requirements. Financial innovations were also used by banks to circumvent reserve requirements. In Brazil, the use of reserve requirements as a liquidity management tool is often justified by the argument that reserve requirements fulfilled a critical liquidity provision role in the fall of 2008 . He argued that Brazilian reserve requirements did not actually serve well the liquidity provision goal.

\section{OBJECTIVES OF THE STUDY}

Almost all economies particularly developing countries have accumulated large stockpiles of international reserves on breakdown of the Bretton Wood system in 1971. They embarked accumulating international reserves to intervene FX markets to get price stability and lessen foreign exchange volatility. The hoarding of these reserves is made irrespective of the opportunity cost and the effects they have on price stability and volatility. Another reason to have large stockpile of international reserves is foreign debt service and international trade activities. The import and export transactions affect foreign exchange reserves as foreign currencies get involved in these transactions. The more export of goods and services will fetch more economic growth. This paper, therefore, assesses how economic growth affects international reserves in Brazil by using error correction model.

Lots of studies are available on international reserves but not much appears to have been done to examine the effect of economic growth on these reserves in case of Brazil. This study contributes to international reserves literature by examining the effect that economic growth has on international reserves in Brazilian context over the period spanning from 1980 to 2014. Hence, this paper is to add to existing knowledge. Also there will be some information on hoarding of international reserves and economic growth relationship. The findings will thus enrich the existing literature. The main aim of this study is to find why Brazil hoard large stockpiles of reserves. Other objective is to explore the impact that economic growth has on international reserves.

\section{DATA DESCRIPTION AND METHODOLOGY}

The present study deals with extensive literature review which takes in the areas of international reserves and economic growth of Brazil. Time series data for a period of 35 years ranging from 1980 to 2014 were collected from World Development Indicators (WDI) of the World Bank. The variables are arranged as dependent and independent variable. Dependent variable is international reserves (IR) measured as total international reserves excluding gold. Independent variable is economic growth (ECON) proxied by real GDP. All the variables are taken in their real values. We develop a model below relating international reserves to economic growth. 


$$
(\mathrm{IR})_{\mathrm{t}}=\beta_{1}+\beta_{2}(\mathrm{ECON})_{\mathrm{t}}+\mathrm{e}_{\mathrm{t}}
$$

Where, (IR) is total international reserves minus gold divided. (ECON) is economic growth captured by real GDP. $\beta_{1}$ and $\beta_{2}$ are regression coefficients for the model and $e_{t}$ is an error term.

\section{EMPIRICAL RESULTS}

Our objective is to see both short run and long run relationship between international reserves and economic growth. It is usual practice to check the stationarity issues in the analysis of time series data. To examine the stationarity properties of our data we applied Augmented Dickey Fuller (ADF) and Phillips-Perron (PP) unit root tests. All the variables were found non-stationary at level but after first differencing they became stationary showing the integration order of I (1). Table 1 reports Augmented Dickey Fuller (ADF) and Phillips-Perron (PP) tests for the order of integration for each variable.

Table 1: Unit Root Tests

\begin{tabular}{|c|c|c|c|c|}
\hline \multicolumn{3}{|c|}{ Augmented Dickey Fuller (ADF) } & \multicolumn{2}{c|}{ Phillips-Perron (PP) } \\
\hline Variables & Level & $1^{\text {st }}$ difference & Level & $1^{\text {st }}$ difference \\
\hline IR & 0.401 & $-3.297^{*}$ & 1.322 & $-3.263^{*}$ \\
\hline ECON & 0.658 & $-4.278^{*}$ & 0.395 & $-4.263^{*}$ \\
\hline
\end{tabular}

* denotes rejection of null hypothesis at $5 \%$ significance level.

Since all the variables showed the same order of integration they might be cointegrated. To check co-integration we applied Johansen co-integration test. The test suggested no co-integration. The results of Johansen co-integration are not reported here and available on request. After that we regressed the long run model. The model is shown below

$$
\begin{aligned}
\operatorname{Ln}(I R)_{t}= & -24.694+0.160(E C O N)+e_{t} \\
& (-8.325) *(28.656) *
\end{aligned}
$$

$$
\text { Adjusted } \mathrm{R}^{2}=0.96 \quad \mathrm{DW}=0.95
$$

Note: Figures in parenthesis are the t-statistics.

* indicate significant at 1 per cent level.

As per this model the economic growth is found with expected positive sign and highly significant. The Durbin-Watson statistics is less than R2 suggesting possible spurious regression model. But if the residuals of this model are found stationary at level then long run model will no longer be spurious. Moreover, stationarity of residuals will indicate that variables are co-integrated. We got the residuals of this model. The residuals are found stationary at level so long run model is no 
longer spurious. Moreover, stationarity of residuals signals that variables are cointegrated suggesting for error correction mechanism (ECM).

Having obtained the long run model the next step is to estimate the coefficients of short run dynamics which have important implications. Therefore, an error correction model will be estimated that incorporates the short term interactions and speed of adjustment towards long run equilibrium. The specification of error correction model is presented below:

$$
\Delta(\mathrm{IR}) \mathrm{t}=\beta 0+\beta 1 \Delta(\mathrm{ECON}) \mathrm{t}+\gamma \mathrm{Ut}-1+\text { et }
$$

Where all variables are defined as earlier. Ut-1 is the error correction term (ECT) and $\gamma$ is coefficient of ECT. The expected sign of Ut- 1 is negative and it must be significant. In the estimation the lag length is determined using Akaike's and Schwarz Information Criteria. Both the criteria suggested maximum lag length as two. The results of error correction model are provided as under:

$$
\begin{array}{ccc}
\Delta(\mathrm{IR})_{\mathrm{t}}= & 22.296+0.083 \Delta(\mathrm{ECON})_{\mathrm{t}}- & -0.404 \mathrm{U}_{\mathrm{t}-1} \\
(1.57) & (4.71) & *(-3.17)^{*} \\
\text { Adjusted } \mathrm{R}^{2}=0.44 & & \mathrm{DW}=1.62
\end{array}
$$

Note: Figures in parenthesis are the t-statistics.

*indicate significant at 5 per cent level.

Equation (4) reports regression results of error correction model. The error correction term (ECT) is statistically significant and has the expected negative sign. This ECT provides a measure of average speed of adjustment at which economic growth adjust to a change in equilibrium condition. The absolute value of ECT signals that movement of economic growth towards eliminating disequilibrium within a year is 40.4 percent. At last, we performed the diagnostic tests to our model. To check autocorrelation, we used Breusch-Godfrey serial correlation test. To examine whether the residuals are normally distributed, we employed JarqueBera normality test. For heteroscedasticity, we used Breusch-Pagan-Godfrey heteroskedasticity test and Ramsey RESET test was used to check specification error. The model estimated passed all these tests at 5 percent level. Table 2 reports results corresponding these tests.

Table 2: Diagnostic Tests

\begin{tabular}{|l|c|c|}
\hline \multicolumn{1}{|c|}{ Name of the test } & Statistics & P-Value \\
\hline Breusch-Godfrey serial correlation test & Obs R $=11.10$ & 0.09 \\
\hline Jarque-Bera normality test & 2.04 & 0.36 \\
\hline Breusch-Pagan-Godfrey heteroskedasticity test & Obs R2 $=2.99$ & 0.08 \\
\hline Ramsey RESET test & t-stat. $=4.72$ & 0.00 \\
\hline
\end{tabular}

Source: Authors' calculations. 
Our results suggest that economic growth have positive impact on international reserves. Moreover, 100 units increase in economic growth will lead 160 units upsurge in international reserves holdings. These results can be generalized to argue that economies may have large stockpiles of international reserves for economic growth. This is one of the reasons why Brazil hoard large stockpiles of foreign reserves.

Figure 3: Plot of cumulative sum of recursive residuals

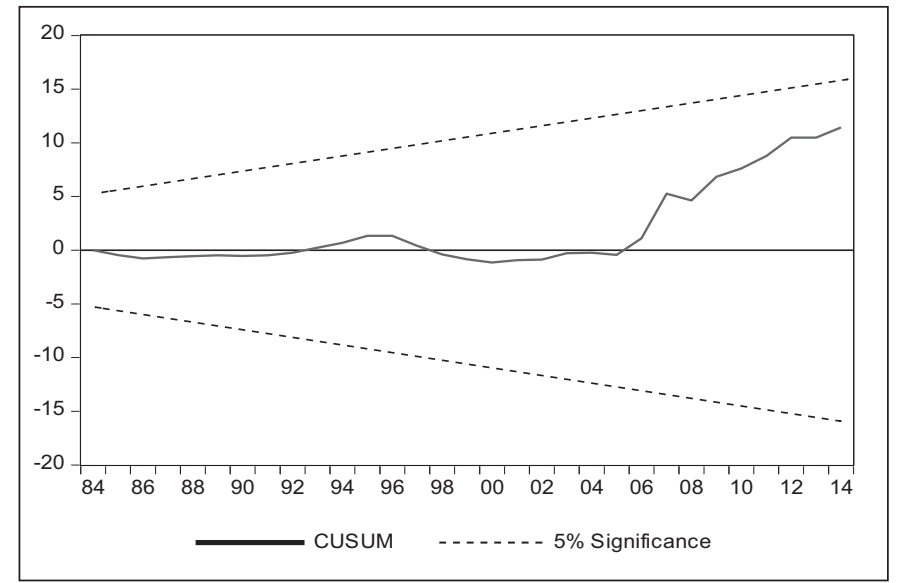

Note: Straight lines are critical bounds at 5 percent level of significance.

\section{LIMITATIONS OF THE STUDY}

1. The study employed annual data. Further research may be carried out taking large data sample of some low frequency.

2. We didn't consider the cost of accumulation of international reserves. Future research may include this variable to improve the results.

3. Several other factors may also impact foreign exchange reserves. We took only economic growth, the study can be more generalized taking some other factors.

\section{CONCLUSION}

This study analyzed the dynamic relationship between economic growth and international reserves in the context of error correction model. The model was estimated for the economy of Brazil over the 1980-2014 sample period. Several conclusions can be derived from the results. First, each of the series considered in this study were found non-stationary at level. Nelson and Plosser (1982) argued that inferences based on time series containing stochastic trend or unit root feature are less straightforward than in the case of stationary data. Therefore, we con- 
verted our data into stationary by using Augmented Dickey Fuller and PhillipsPerron unit root test.

Second, we ran the regression model in which the Durbin-Watson statistic was found less than the coefficient of determination suggesting possible spurious regression model, but when we checked the residuals of this model, it indicated long run relationship between the variables and suggested for error correction model to check short run dynamics too. Third, the error correction term (ECT) validated our model for being negative and statistically significant at 5 percent level. The absolute value of ECT signals that movement of economic growth towards eliminating disequilibrium within a year is 40.4 percent. Fourth, the model estimated under this study passed all the diagnostic tests such as Breusch-Godfrey serial correlation test; Jarque-Bera normality test; Breusch-Pagan-Godfrey heteroskedasticity test and Ramsey RESET test for specification error.

Finally, we argue that economic growth has positive impact on international reserves in Brazil. Our results reveal that, ceteris paribus, 1 per cent increase in economic growth will lead 0.16 per cent upsurge in international reserves holdings of Brazil. These results can be generalized to argue that large stockpiles of international reserves may be due to foreign trade and economic growth. This is one of the reasons why Brazil hoard large stockpiles of foreign reserves. Therefore, it seems reasonable to accumulate a sufficient amount of international reserves by Banco Central do Brasil.

\section{REFERENCES}

Aizenman, Joshua \& Marion, Nancy (2003) "The high demand for international reserves in the Far East: What is going on?", Journal of the Japanese and International Economics (17): 370-400.

Aizenman, Joshua and Lee, Jawoo (2007) "International Reserves: Precautionary Versus Mercantilist Views, Theory and Evidence”, Open Economies Review (18): 191-214.

Azzoni, Carlos (2001) "Economic Growth and Regional income inequality in Brazil", The Annals of Regional Science 35(1): 133-152.

Bacha, Edmar (1977) “Issues and evidence on recent Brazilian economic growth", World Development 5(1-2): 47-67.

Bahmani-Oskooee, Mohsen \& Brown, Ford. (2002) "Demand for international reserves: a review article”, Applied Economics 34(10): 1209-1226.

Balassa, Bela (1978) "Exports and Economic Growth: Further evidence", Journal of Development Economics 5(2): 181-89.

Bird, Graham \& Ramkishen, Rajan (2003) "Too Much of a Good Thing? The Adequacy of International Reserves in the Aftermath of Crises", The World Economy 26(6): 873-891.

Charles-Anyaogu (2012) "External Reserves: Causality Effect of Macroeconomic Variables in Nigeria", Kuwait Chapter of Arabian Journal of Business and Management Review 1(12): 14-27.

David, A. \& Halliday, Robert (2008) “The rationale for holding foreign currency reserves", Reserve Bank of New Zealand Bulletin 61(4): 156-163.

Dickey, David \& Fuller, Wayne (1979) "Distribution of the Estimators for Autoregressive Time Series with a Unit Root”, Journal of the American Statistical Association 74 (366a): 427-431.

Strauss-Kahn, Dominique (2009) "The Impact of the Financial Crisis on Low-Income Countries" The Brookings Institution, Washington DC, available via the internet at: http://www. brookings. edu// media/Files/events/2009/0303imf/20090303imf. pdf (2009). 
Dooley, Michael; David, Folkerts-Landau and Peter Garber (2003) “An Essay on the Revived Bretton Woods System", No. w9971: National Bureau of Economic Research.

Edwards, Sebastian (1983) "The demand for international reserves and exchange rate adjustments: the case of LDCs 1964-1972”, Economica (50): 269-280.

Engle, Robert \& Granger, Clive (1987) "Cointegration and Error Correction: Representation, Estimation and Testing", Econometrica: Journal of the Econometric Society (55): 251-276.

Feder, Gershon (1983) “On exports and economic growth”, Journal of Development Economics 12(1): 59-73.

Frenkel, Jacob \& Javanovic, Boyan (1981) “Optimal international reserves: a stochastic Framework", The Economic Journal 91(362): 507-514.

Garcia, Pablo \& Soto, Claudio (2004) "Large hoarding of international reserves: Are they worth it?", Central Bank of Chile Working Paper No 299.

Gosselin, Marc-Andre \& Nicolas, Parent (2005) “An Empirical Analysis of Foreign Exchange Reserves in Emerging Asia”, Bank of Canada Working Paper 2005-38.

Jung, Woo \& Marshall, Peyton (1985) “Export growth and Causality in Developing Countries”, Journal of Development Economics 18(1): 1-12.

Kashif, Mohammad \& Sridharan, P (2015) "International reserves accumulation and economic growth: Evidence from India", International Journal of Engineering and Management Research 5(2): 583-589.

Nelson, Charles \& Charles, Plosser (1982) "Trends and Random Walks in Macroeconomics Time Series: Some Evidence and Implications”, Journal of Monetary Economics 10(9): 139-162.

Robitaille, Patrice (2011) “Liquidity and Reserve Requirements in Brazil”, International Finance Discussion Paper number 1021. 